\title{
MULTIVALENT STRUCTURE OF GALECTIN-1-NANOGOLD COMPLEX SERVES AS POTENTIAL THERAPEUTICS FOR RHEUMATOID ARTHRITIS BY ENHANCING RECEPTOR CLUSTERING
}

\author{
Yen-Jang Huang ${ }^{1}$, Ai-Li Shiau ${ }^{2 *}$, Shih-Yao Chen ${ }^{1}$, Yuh-Ling Chen ${ }^{3}$, Chrong-Reen Wang ${ }^{4}$, Chiau-Yuang Tsai ${ }^{1}$, \\ Meng-Ya Chang ${ }^{1}$, Yuan-Tsung $\mathrm{Li}^{1}$, Chia-Hsing Leu ${ }^{1}$ and Chao-Liang $\mathrm{Wu}^{1,3, *}$ \\ ${ }^{1}$ Department of Biochemistry and Molecular Biology, \\ ${ }^{2}$ Department of Microbiology and Immunology, \\ ${ }^{3}$ Institute of Oral Medicine, \\ ${ }^{4}$ Section of Rheumatology and Immunology, Department of Internal Medicine, \\ National Cheng Kung University Medical College, Tainan, Taiwan
}

\begin{abstract}
Cellular behaviour is controlled by numerous processes, including intracellular signalling pathways that are triggered by the binding of ligands with cell surface receptors. Multivalent ligands have multiple copies of a recognition element that binds to receptors and influences downstream signals. Nanoparticle-ligand complexes may form multivalent structures to crosslink receptors with high avidity and specificity. After conjugation of galectin-1 onto gold nanoparticles, the resulting nanogold-galectin-1 (AuGal1) bound with higher affinity to Jurkat cells to promote CD45 clustering and inhibition of its phosphatase activity, resulting in enhancement of apoptosis via caspase-dependent pathways. Au-Gall injected intra-articularly into rats with collagen-induced arthritis (CIA) promoted apoptosis of $\mathrm{CD}^{+} \mathrm{T}$ cells and reduced pro-inflammatory cytokine levels in the ankle joints as well as ameliorated clinical symptoms of arthritis. These observed therapeutic effects indicate that the multivalent structure of nanoparticle-ligands can regulate the distribution of cell surface receptors and subsequent intracellular signalling, and this may provide new insights into nanoparticle applications.
\end{abstract}

Keywords: Rheumatoid arthritis, ankle joint, apoptosis, cell-surface receptors, galectin-1, gold, inflammation, nanoparticles.

*Addresses for correspondence:

Chao-Liang Wu

Department of Biochemistry and Molecular Biology

or Ai-Li Shiau

Department of Microbiology and Immunology

National Cheng Kung University Medical College

1 University Road, Tainan 70101, Taiwan

Telephone Number: +886-6-2353535x5536

FAX Number: +886-6-2741694

E-mail:wumolbio@mail.ncku.edu.tw

E-mail: alshiau@mail.ncku.edu.tw

\section{Introduction}

Surface receptors play an important role in mediating the interface between a cell and its external environment. These molecules bind specific ligands to control numerous aspects of intracellular signalling (Shankaran et al., 2007). Multivalent ligands display multiple copies of recognition elements on the same scaffold, which allows for numerous ways in which receptors and ligands can interact (Gestwicki et al., 2002). Multivalent ligands bind multiple receptors and crosslink membrane receptors more efficiently to regulate the intensity and duration of intracellular signalling and subsequent responses. Nanoparticles coated with multiple ligands can act as multivalent ligands capable of crosslinking surface receptors (Jiang et al., 2008). Characterisation of nanoparticle platforms may provide a novel strategy to modulate cell signalling and develop therapeutic and diagnostic agents.

Galectin-glycoprotein lattice formation in T cells plays a critical role in regulating the threshold of signalling events, such as survival, activation and cytokine secretion (Rabinovich et al., 2007; Garner and Baum, 2008). Galectin-1 is a non-covalent homodimer consisting of subunits with a carbohydrate recognition domain responsible for $\beta$-galactoside binding in the reduced form, whereas the oxidised form containing intramolecular disulphide bonds is monomeric in structure and does not bind carbohydrates (Inagaki et al., 2000). Galectin-1 induces apoptosis of specific thymocyte subsets and activates $T$ cells. The specific receptors involved in galectin-1-mediated T cell death are CD7, CD43 and CD45 (Camby et al., 2006). CD45 comprises up to $10 \%$ of total cell surface proteins in $\mathrm{T}$ cells and regulates the signalling thresholds of receptors expressed on immune cells. The intracellular phosphatase domain of CD45 contributes to the majority of the tyrosine phosphatase activity in T cells and is critical for initiating T cell receptor-mediated signals (Hermiston et al., 2003; Trowbridge and Thomas, 1994). $\mathrm{CD} 45$, the major receptor for galectin-1 on T cells, acts as a negative or positive regulator of galectin-1-induced cell death and enhances phagocytic clearance of cells killed by galectin-1 (Walzel et al., 1999: Fouillit et al., 2000; Nguyen et al., 2001; Amano et al., 2003; Pang et al., 2009; Earl et al., 2010). Galectin-1 binds to the CD45 extracellular domain and reduces the tyrosine phosphatase activity of CD45 by receptor clustering (Walzel et al., 1999; Nguyen et al., 2001). The clustering of receptors 
is essential for galectin-1-mediated cell death of CD45expressing T cells, although the mechanism of this process is unknown (Fouillit et al., 2000; Amano et al., 2003; Pang et al., 2009; Earl et al., 2010).

Rheumatoid arthritis (RA) causes chronic inflammation and joint destruction, and there is no effective therapy capable of improving disease symptoms and lessening joint destruction (Van der Heijde, 1995). The pro-inflammatory cytokines secreted from Th1 and Th17 T cells play an important role in the pathogenesis of RA. Galectin-1 can selectively bind Th1 and Th17 T cells due to differential glycosylation on their surface and induce cell death; it also acts to regulate cytokines by promoting Th2 cytokine production in Th2 cells (Toscano et al., 2007; Motran et al., 2008). However, the prophylactic and therapeutic effects of recombinant galectin-1 protein or galectin-1 gene delivery on collagen-induced arthritis (CIA) in animal models that mimic human RA have been shown to be limited (Rabinovich et al., 1999; Wang et al., 2010). We have previously demonstrated similar prophylactic activity by intra-articular administration of nanogold (Tsai et al., 2007). However, the observed prophylactic effects were not significant enough for clinical use. Here, we developed nanogold-galectin-1 (Au-Gal1) complexes with multivalent structure to increase galectin-1 binding affinity to receptors and increase apoptotic signals by crosslinking CD45 on T cells. We expect that this multivalent property of Au-Gall complexes will have more therapeutic potential than free-form galectin-1 or nanogold for RA.

\section{Materials and Methods}

\section{Protein adsorption}

The protein concentration was required to stabilise the gold nanoparticles after $10 \% \mathrm{NaCl}$ was added to the nanoparticle solution. The protein amount was added to 1 $\mathrm{mL}$ of gold nanoparticle solution while stirring for $1 \mathrm{~min}$. Following an additional $10 \mathrm{~min}$ of stirring, the solution was centrifuged at $12,000 \mathrm{~g}$ (at $4{ }^{\circ} \mathrm{C}$ ) for $30 \mathrm{~min}$ to remove unbound excess proteins. The pellet was resuspended in $0.01 \mathrm{M}$ sodium phosphate buffer ( $\mathrm{pH}$ 7.4). The protein concentration in the supernatant was measured using a micro BCA assay kit (Thermo Scientific Pierce, Rockford, IL, USA). The amount of protein bound to the surface of gold nanoparticles was calculated using the following formula: Protein bound to gold nanoparticles $=$ Total protein added - Protein in the supernatant solution (Jiang et al., 2008).

\section{Binding avidity}

Jurkat cells were cultured in 96 -well plates to $80 \%$ confluency. Cells were fixed using $2 \%$ paraformaldehyde and blocked with $1 \%$ bovine serum albumin (BSA) for $30 \mathrm{~min}$. Cells were incubated with varying concentrations of galectin-1 and Au-Gall for $1 \mathrm{~h}$ and then washed in phosphate-buffered saline (PBS) containing $0.1 \%$ Tween 20 (PBST) to remove the unbound galectin-1 and AuGal1. Cells were treated with a biotinylated anti-galectin-1 antibody (R\&D, Minneapolis, MN, USA) for $1 \mathrm{~h}$, and then cells were washed in PBST. After streptavidinconjugated horseradish peroxidase was added for $30 \mathrm{~min}$, tetramethylbenzidine was added. Following a $20 \mathrm{~min}$ incubation, $2 \mathrm{~N} \mathrm{H}_{2} \mathrm{SO}_{4}$ was added to stop the reaction. Absorbance was measured at $450 \mathrm{~nm}$ (Jiang et al., 2008).

\section{Cell viability}

Jurkat cells $\left(1 \times 10^{4}\right)$ were plated in 96-well plates and incubated with different concentrations of galectin-1 or Au-Gall in serum-free RPMI medium. Following $6 \mathrm{~h}$ incubation, cells were incubated at $37{ }^{\circ} \mathrm{C}$ with $5 \% \mathrm{CO}_{2}$ in RPMI medium supplemented with $5 \%$ foetal bovine serum (FBS) for $72 \mathrm{~h}$. Cell viability was determined by trypan blue exclusion.

\section{Western blot analysis}

Jurkat cells $\left(1 \times 10^{6}\right)$ were incubated under various conditions and washed three times with PBS. Cells were lysed with NP40 lysis buffer. Proteins were extracted by centrifugation and loaded onto a gel at a concentration of $20 \mu \mathrm{g}$ per well. Total protein was resolved by SDS-PAGE (polyacrylamide gel electrophoresis) and transferred onto a nitrocellulose membrane. The proteins involved in the galectin-1 signalling cascade, such as phosphorylated tyrosine (p-Tyr), caspase- 8 and caspase-3, were detected using specific antibodies (Santa Cruz, Santa Cruz, CA, USA) and horseradish peroxidase-labelled goat antimouse IgG (Jackson, West Grove, PA, USA). The labelled membranes were incubated in an ECL working solution before imaging with the VersaDoc Model 5000 BioRad (Hercules, CA, USA) Imaging System.

\section{CD45 clustering assay}

For analysis of CD45 clustering, cells treated with galectin-1 or Au-Gal1 were fixed for 30 min with $2 \%$ (wt/ vol) paraformaldehyde and incubated for $1 \mathrm{~h}$ with a mouse monoclonal antibody to human CD45 (Santa Cruz) and biotin-labelled goat anti-mouse IgG. Cells showing CD45 aggregation were counted under a microscope.

\section{Induction of CIA and delivery of Au-Gal1}

To induce experimental arthritis of the ankle joint, male Sprague-Dawley rats at 8 weeks of age were immunised intradermally with $400 \mu \mathrm{g}$ and $240 \mu \mathrm{g}$ on days 0 and 8 , respectively, of bovine type II collagen (Elastin Products, Owensville, MO, USA) emulsified in Freund's incomplete adjuvant (Difco, Detroit, MI, USA) (Chen et al., 2011; Shiau et al., 2007). On day 14, they were injected intraarticularly with recombinant galectin-1 protein $(40 \mu \mathrm{g})$, Au-Gal1 (containing $40 \mu$ g galectin-1), Au-BSA, Au or PB. There was $360 \mu \mathrm{g}$ of nanogold in the Au-Gall and Au-BSA samples for treatment.

\section{Clinical and radiographic assessment}

The articular index was scored on a $0-4$ scale $(0=$ no swelling or erythema, 1 = slight swelling and/or erythema, 2 = low to moderate oedema, 3 = pronounced oedema with limited joint usage, 4 = excess oedema with joint rigidity). Ankle circumference was determined using the following geometric formula: $\left.2 \pi\left(\sqrt{[} a^{2}+b^{2} / 2\right]\right)$, where $a$ is the laterolateral diameter and $b$ is the anteroposterior diameter. The ankles were examined radiographically after the rats were sacrificed on day 24. Radiographs were scored on a 
A

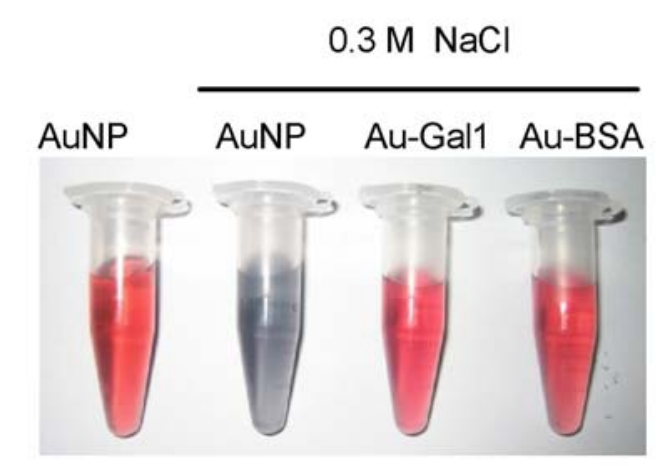

C

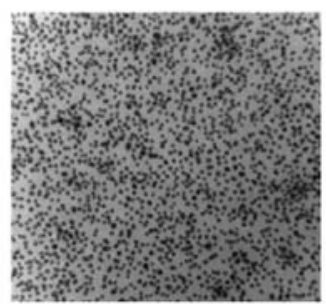

D
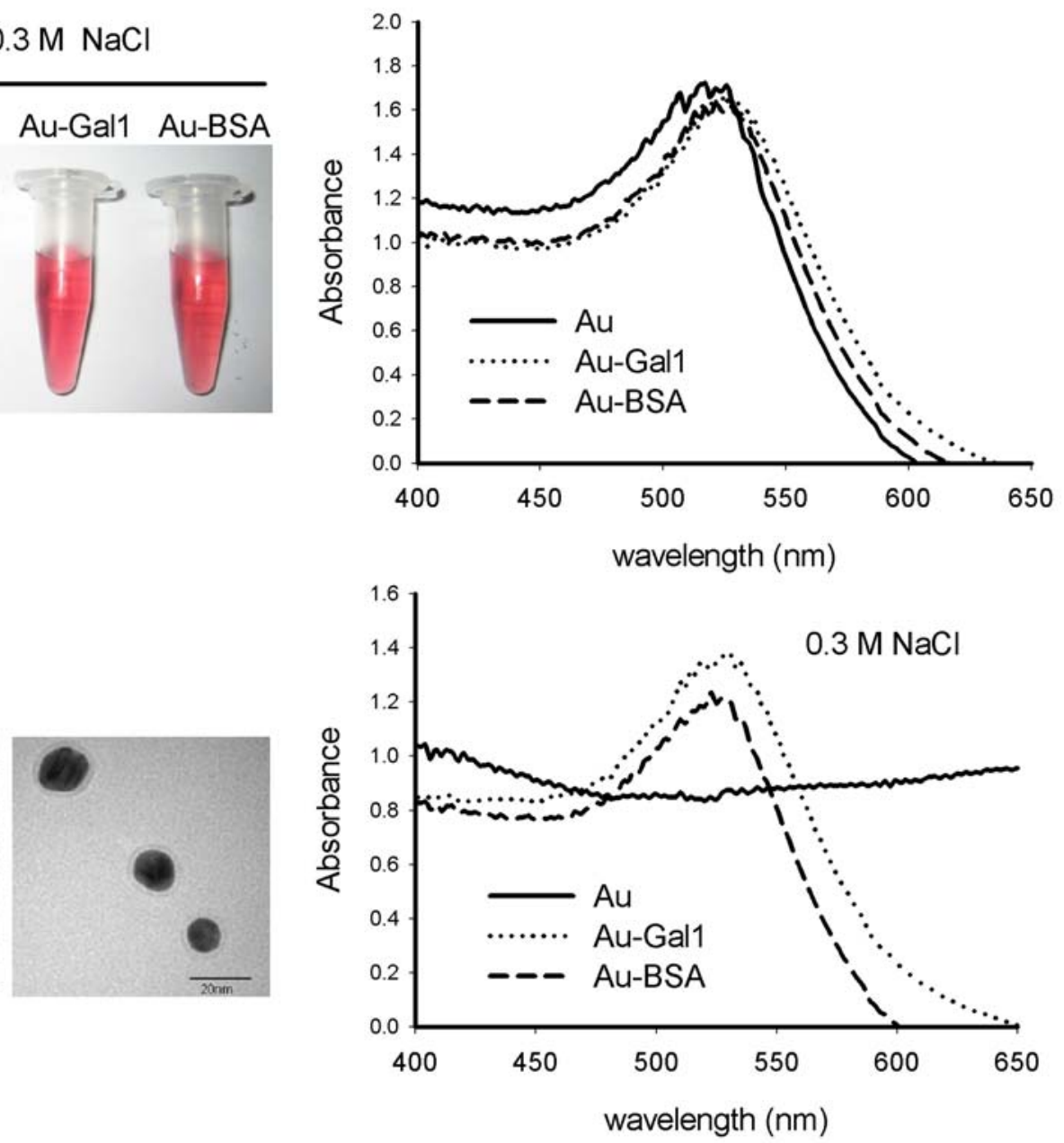

Gal-1

$\begin{array}{lllllllllllll}160 & 80 & 40 & 20 & 10 & 5 & 2.5 & 1.25 & 0.625 & 0.312 & 0.156 & 0.078 & \mu \mathrm{gg} / \mathrm{ml}\end{array}$
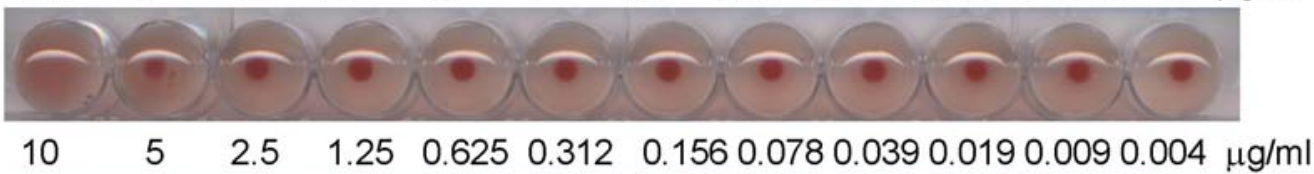

Negative control

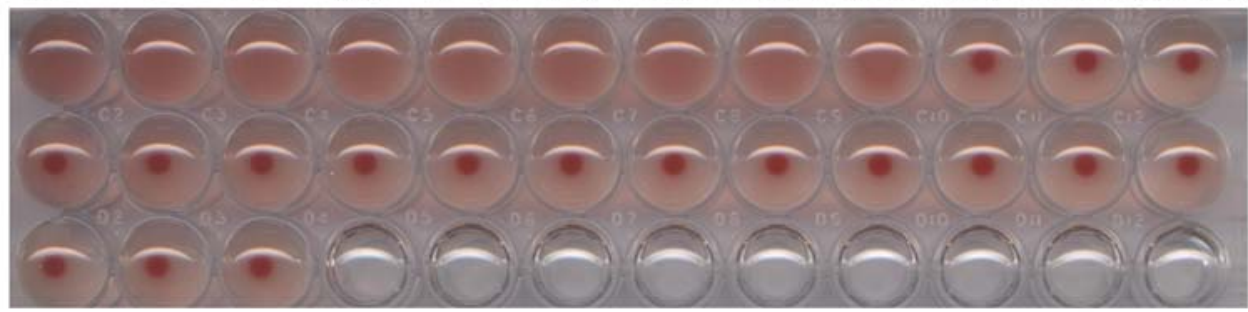

Fig. 1. Properties of Au-Gal1. (A) The stability of Au-Gall following addition of NaCl. (B) Spectroscopic detection of $\mathrm{Au}, \mathrm{Au}-\mathrm{Gall}$ and $\mathrm{Au}-\mathrm{BSA}$ in $\mathrm{NaCl}$ solution. (C) TEM images of Au-Gal1. Scale bar $=20 \mathrm{~nm}$. (D) Haemagglutination assay of galectin-1, Au-Gal1 and Au-BSA. Serial two-fold dilutions of galectin-1, Au-Gal1 or Au-BSA were mixed with $0.4 \%$ human O-type RBC suspension in U-shaped 96-well plates at room temperature for $30 \mathrm{~min}$. RBC alone served as the negative control for haemagglutination.

0-10 scale and were based on the width of the joint space, degree of bone destruction, and soft-tissue swelling (Wang et al., 2005).

\section{Histopathologic and immunohistochemical} assessment

Sections of paraffin-embedded ankle joints were prepared, stained with haematoxylin and eosin, and evaluated for the presence of synovial hyperplasia, cartilage erosion, and leukocyte infiltration. The sections were also stained with a polyclonal rabbit anti-von Willebrand factor antibody (Dako, Carpinteria, CA, USA) for microvessels, a mouse anti-rat monocyte/macrophage monoclonal antibody (ED1; Chemicon, Temecula, CA, USA) for infiltrating macrophages and a goat anti-rat CD4 monoclonal antibody (Shiau et al., 2007). Frozen sections of ankle joints were 
also subjected to immunofluorescence staining with mouse anti-rat CD4 monoclonal antibody (BD PharMingen, San Diego, CA, USA) and Pand Alexa fluor594 goat antimouse IgG (Invitrogen, Carlsbad, CA, USA). Apoptotic cells were assessed with a DeadEnd colorimetric terminal deoxynucleotidyl transferase-mediated dUTP nick end labelling (TUNEL) assay kit (Promega, Madison, WI, USA).

\section{Enzyme-linked immunosorbent assay (ELISA)}

After induction of experimental arthritis, the ankle joints were injected intra-articularly with recombinant galectin-1 protein and Au-Gall in $50 \mu \mathrm{L}$ of phosphate buffer (PB) on day 14. The levels of TNF- $\alpha$, IFN- $\gamma$, IL-4, and IL-17 in the ankle homogenates of rats with CIA on day 16 were determined by ELISA (R\&D, Minneapolis, MN, USA).

\section{Statistical analysis}

Data are expressed as mean \pm SEM. Differences in rat articular index scores between two groups were examined by repeated-measures analysis of variance using SAS software, version 9.1 (GLM program; SAS Institute, Cary, NC, USA). Differences in the remaining data between two groups were compared by Student's $t$-test. $P$ values less than 0.05 were considered significant.

\section{Results}

\section{Au-Gal1 complexes preserved the biological activity of galectin-1}

To achieve the physical properties of a multivalent structure with nanoparticle-ligand complexes, a novel formulation of Au-Gall complexes in which recombinant human galectin-1 was conjugated onto a $13 \mathrm{~nm}$ nanogold surface was prepared. Au-Gall remained red in colour without an absorption spectrum shift when it was subjected to a $0.3 \mathrm{M} \mathrm{NaCl}$ solution, suggesting that the galectin-1 protein had good coverage on the particle surface to protect from particle aggregation in high-salt solution (Fig. 1A,B). Transmission electron microscopy (TEM) also demonstrated that Au-Gall had a uniform spherical structure with dispersed characteristics and was stable in the $\mathrm{NaCl}$ solution (Fig. 1C). The total size of the $\mathrm{Au}-\mathrm{Gall}$ complexes was approximately $15 \mathrm{~nm}$, which included the $13 \mathrm{~nm}$ gold nanoparticle core and the $1 \mathrm{~nm}$ layer of galectin-1 protein bound to the particle surface. On average, there were $100 \mathrm{mg}$ of galectin-1 bound to $1 \mathrm{~g}$ of gold nanoparticles, which was equivalent to 66 galectin-1 molecules on a single $13 \mathrm{~nm}$ particle. To examine whether Au-Gall remained as biologically active as free galectin-1, a haemagglutination assay was performed. The lowest concentration required for Au-Gall to induce haemagglutination activity was as low as $0.039 \mu \mathrm{g} / \mathrm{mL}$, whereas for free galectin-1, it was $160 \mu \mathrm{g} / \mathrm{mL}$, indicating that Au-Gall exhibited a higher bioactivity than free galectin-1 (Fig. 1D).

\section{Au-Gal1 enhanced T cell apoptosis via a caspase- dependent pathway}

Galectin-1 is an important immune regulator that maintains $\mathrm{T}$ cell homeostasis by activating apoptosis through a caspase-dependent pathway (Brandt et al., 2008). We therefore evaluated whether Au-Gall was still able to induce apoptosis in $\mathrm{T}$ cells. Jurkat cells agglutinated upon treatment with either galectin-1 or Au-Gall but not upon mock or Au control treatments. This finding is in agreement with previous studies demonstrating that galectin-1 causes cell agglutination by crosslinking cell surface glycoconjugates (Lange et al., 2009). However, the interaction between Au-Gall and Jurkat cells was abolished by the addition of lactose, suggesting that Au-Gall bound Jurkat cells in a carbohydrate-dependent manner, that galectin-1 bound to the gold nanoparticle was in its reduced form and that the nanogold particle did not interfere with the interaction between galectin-1 and Jurkat cells (Fig. 2A). Furthermore, Au-Gall inhibited Jurkat cell proliferation after $72 \mathrm{~h}$ at an 8 -fold lower concentration than that of galectin-1 (Fig. 2B), and this inhibition was attenuated by the addition of lactose (Fig. 2B). Addition of equal amounts of Au-BSA or nanogold alone had no effects on Jurkat cell proliferation (Fig. 2C). To further examine the reduction in cell growth, the induction of cell death by $\mathrm{Au}-\mathrm{Gal} 1$ through caspase activation and DNA fragmentation were investigated. Full-length procaspase- 8 p57 was cleaved to form caspase- 8 p41/43 in Jurkat cells treated with $\mathrm{Au}-\mathrm{Gall}$, whereas less caspase- 8 activation was observed in cells treated with galectin-1, Au-BSA or $\mathrm{Au}$. The procaspase- 8 processing resulting from $\mathrm{Au}-$ Gall treatment was blocked by $40 \mathrm{mM}$ lactose treatment (Fig. 2D). As a proteolytic signalling cascade is utilised by cells to activate caspases, we examined the effect of Au-Gall treatment on other caspases. As expected, a similar phenomenon was observed with procaspase-3; procaspase-3 p35 was processed to caspase-3 p20 after AuGall treatment, and this process was strongly attenuated in the presence of lactose (Fig. 2D). In addition, DNA fragmentation caused by cell apoptosis was only observed in Jurkat cells treated with Au-Gall (Fig. 2E). These results indicate that the induction of apoptosis in $\mathrm{T}$ cells by galectin-1 was augmented after galectin-1 was bound to gold nanoparticles.

\section{Au-Gal1 increased binding affinity and CD45 clustering}

The multivalent structure of Au-Gall may affect the binding avidity of galectin-1 to Jurkat cells. Therefore, the dissociation constant $\left(\mathrm{K}_{\mathrm{D}}\right)$ values between Au-Gal1 and galectin- 1 were compared. The $\mathrm{K}_{\mathrm{D}}$ value of galectin-1 binding to Jurkat $\mathrm{T}$ cells was $22.81 \times 10^{-11} \mathrm{M}$, whereas it was $2.39 \times 10^{-11} \mathrm{M}$ for Au-Ga11 binding to the same cells (Fig. $3 \mathrm{~A})$. The 10-fold stronger affinity of Au-Gall for Jurkat cells demonstrated by $\mathrm{K}_{\mathrm{D}}$ may suggest prolonged receptor binding. We therefore evaluated whether clusters formed directly after Au-Gal1 binding. The localisation of CD45 on the cell surface was examined by confocal microscopy, and the percentage of cells with clustered CD45 molecules was calculated. Treatment of Jurkat T cells with Au-Gal1 resulted in an approximately 4-fold increase in CD45 molecules when compared with Jurkat cells treated with free galectin-1 (Fig. 3B,C). CD45 clustering on cells after galectin-1 binding has been suggested to facilitate autoinhibition of intracellular protein tyrosine phosphatase 
A

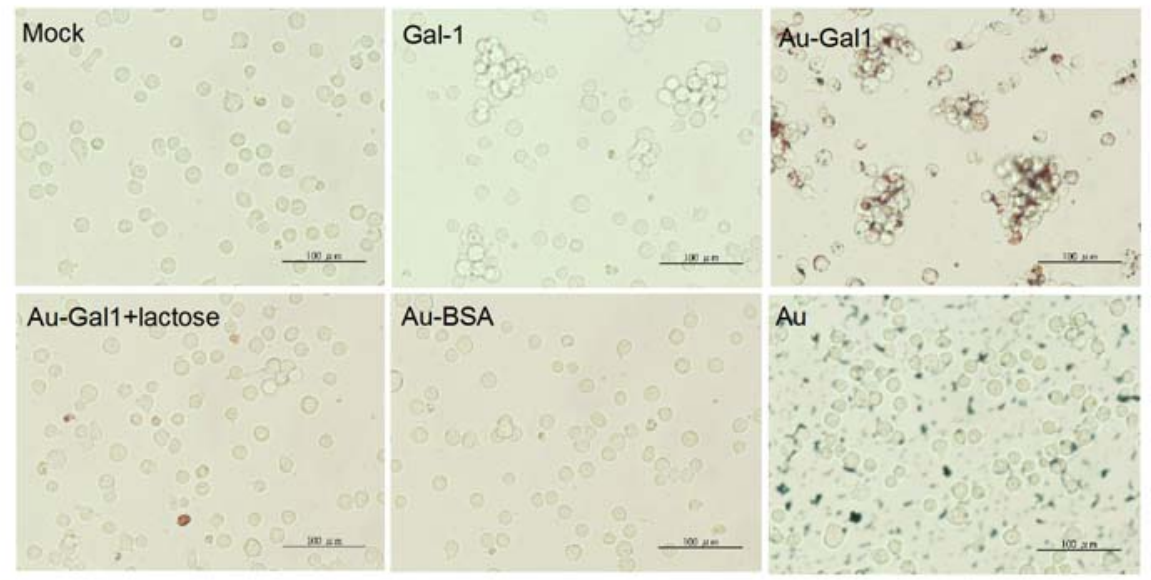

B

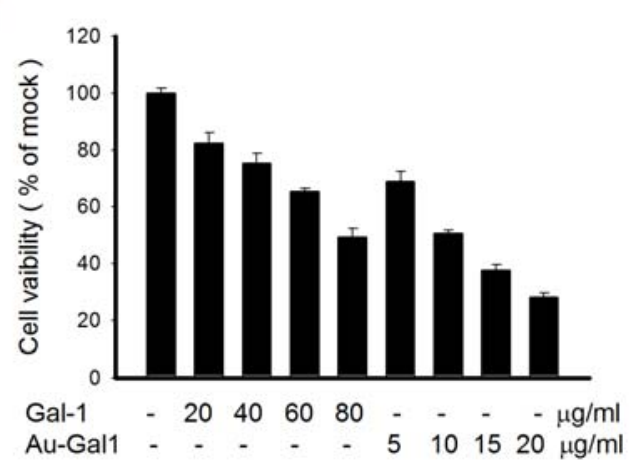

D

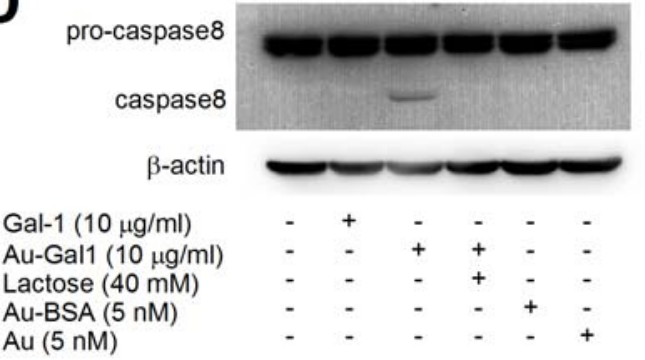

pro-caspase 3

caspase 3

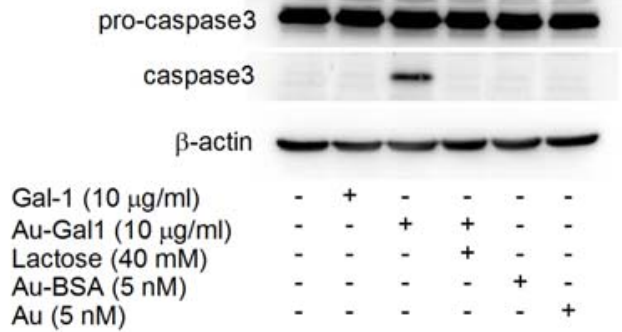

C

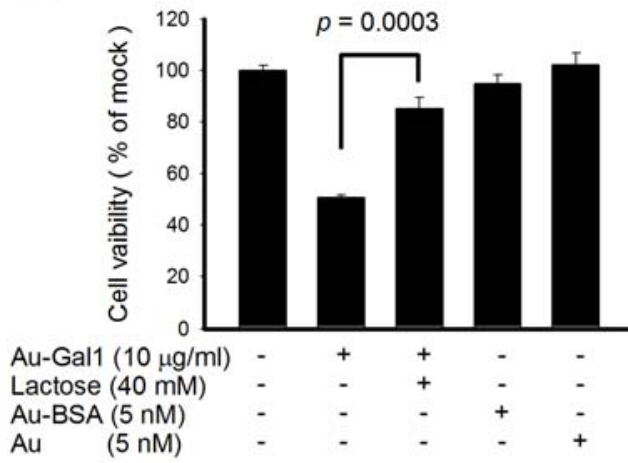

$\mathbf{E}$

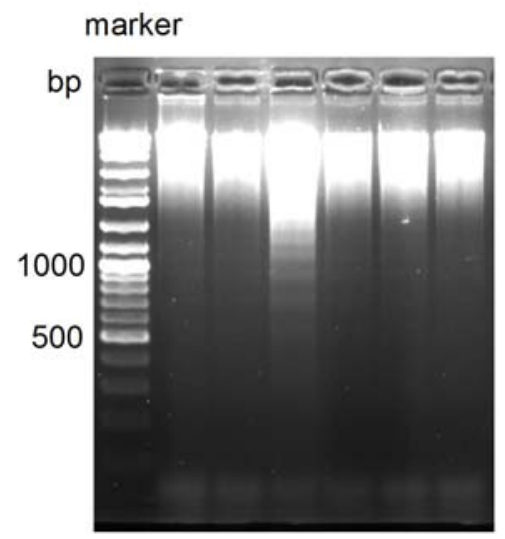

Gal-1 $(10 \mu \mathrm{g} / \mathrm{ml})$

Au-Gal1 $(10 \mu \mathrm{g} / \mathrm{ml})$

Lactose $(40 \mathrm{mM})$

Au-BSA (5 nM)

$\mathrm{Au}(5 \mathrm{nM})$

Fig. 2. Au-Gall induced apoptosis in Jurkat cells. (A) Cells $\left(2 \times 10^{6} /\right.$ well) cultured in 6-well plates were treated with galectin-1 $(10 \mu \mathrm{g})$ with or without the concomitant addition of lactose $(40 \mathrm{mM})$, or with $5 \mathrm{nM}$ particle concentration of Au-Gall, $\mathrm{Au}-\mathrm{BSA}$ or $\mathrm{Au}$ for $30 \mathrm{~min}$. Cells were examined for agglutination with an inverted phase microscope. Scale bar $=100 \mu \mathrm{m}$. (B) Cells $\left(1 \times 10^{4} /\right.$ well $)$ cultured in 96-well plates were treated with various concentrations of galectin- 1 or Au-Gal1 for $6 \mathrm{~h}$ at $37^{\circ} \mathrm{C}$. They were further incubated in RPMI medium supplemented with $5 \% \mathrm{FBS}$ for $72 \mathrm{~h}$. Cell viability was determined by trypan blue exclusion. (C) Cells $\left(1 \times 10^{4} /\right.$ well $)$ cultured in 96 -well plates were treated with Au-Gal1 $(10 \mu \mathrm{g} / \mathrm{mL})$ in the presence or absence of lactose $(40 \mathrm{mM})$, or with $5 \mathrm{nM}$ particle concentration of Au-BSA or Au for $6 \mathrm{~h}$ at $37^{\circ} \mathrm{C}$. They were further incubated in RPMI medium supplemented with $5 \%$ FBS for $72 \mathrm{~h}$, and their viability was determined by trypan blue exclusion. (D) Cells $\left(1 \times 10^{6}\right)$ treated as described in c were subjected to immunoblot analysis for caspase- 8 after $8 \mathrm{~h}$ and for caspase- 3 after $10 \mathrm{~h}$. (E) Cells $\left(2 \times 10^{6} / \mathrm{mL}\right)$ treated as described in c for $12 \mathrm{~h}$. DNA extracted from the treated cells were separated by electrophoresis in $1.5 \%$ agarose gels for detection of DNA ladder formation. 

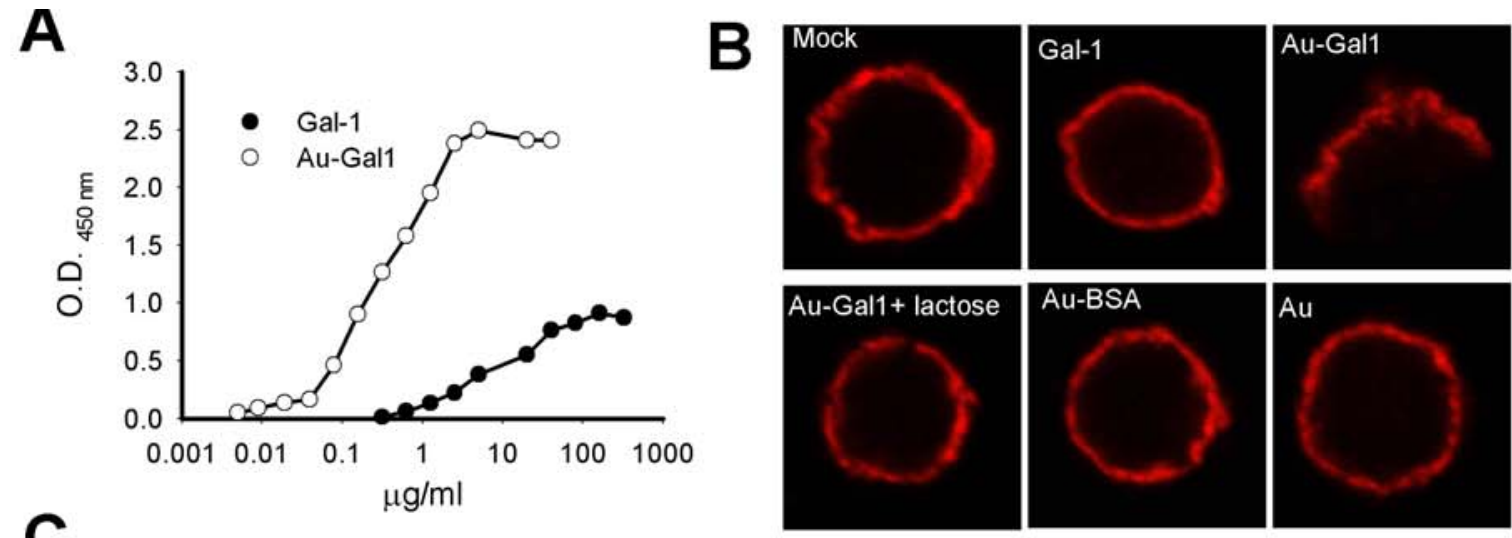

C

$$
p<0.0001
$$

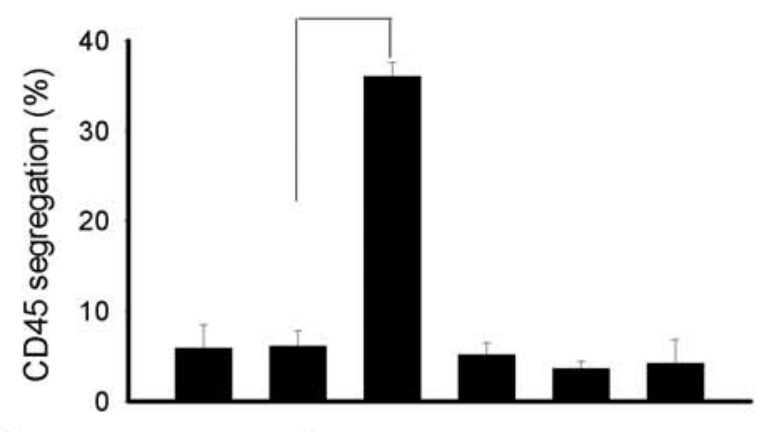

Gal-1 $(10 \mu \mathrm{g} / \mathrm{ml})$ Au-Gal1 $(10 \mu \mathrm{g} / \mathrm{ml})$ Lactose (40 mM) Au-BSA ( $5 \mathrm{nM}$ ) $\mathrm{Au}(5 \mathrm{nM})$

D

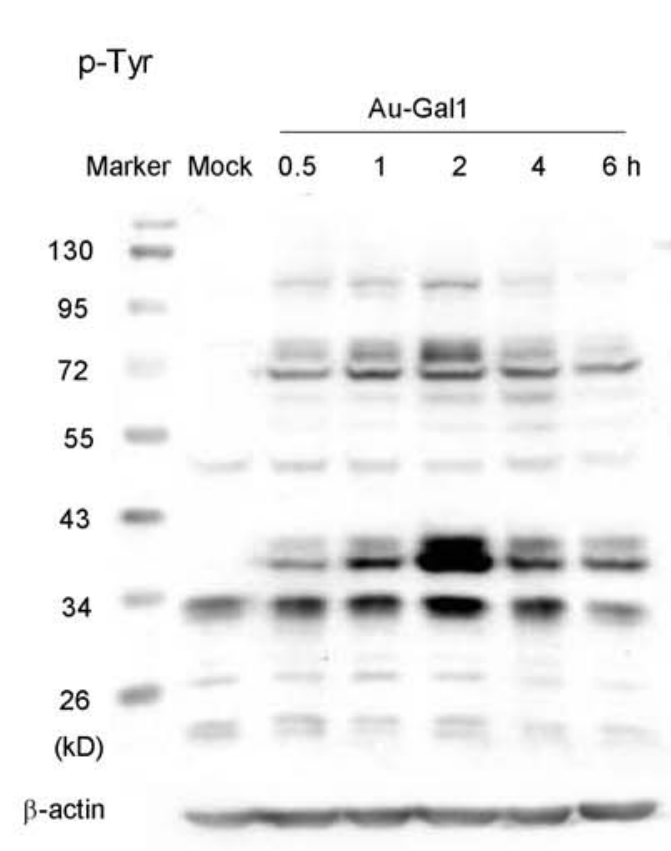

E
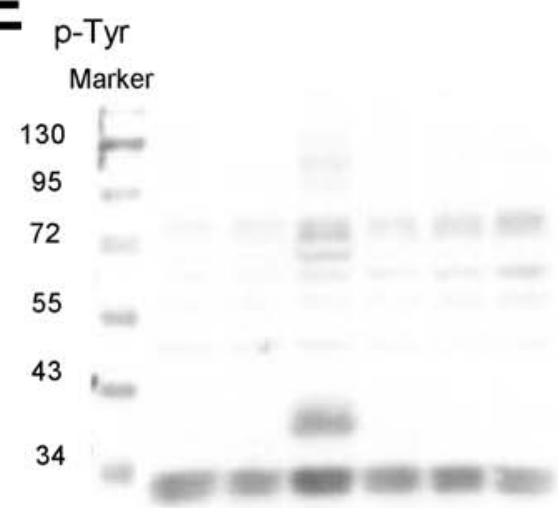

26

(kD)

$\beta$-actin

Gal-1 $(10 \mu \mathrm{g} / \mathrm{ml})$ Au-Gal1 $(10 \mu \mathrm{g} / \mathrm{ml})$ Lactose $(40 \mathrm{mM})$ Au-BSA (5 nM) $\mathrm{Au}(5 \mathrm{nM})$

Fig. 3. Binding affinity of Au-Gall influenced CD45 clustering and signalling. (A) Binding avidity analysis: dissociation constant $\left(\mathrm{K}_{\mathrm{D}}\right)$ values for galectin-1 and Au-Gal1. (B) Laser confocal microscopy of cells incubated with galectin-1 or Au-Gal1. Cells were fixed and stained with a mouse monoclonal anti-human CD45 antibody and biotinlabelled goat anti-mouse IgG. (C) Percentage of CD45 clustering was calculated as follows 100×(CD45 clustering cells/total cells). Cells showing CD45 clustering were counted in three fields for each group. Data represent the mean \pm SEM of four independent experiments. (D) Au-Gal1 induced tyrosine phosphorylation in Jurkat cells. Jurkat cells were stimulated with $10 \mu \mathrm{g} / \mathrm{mL}$ of Au-Gal1 at $37^{\circ} \mathrm{C}$. (E) Cells were stimulated with galectin-1 or Au-Gal1 for $2 \mathrm{~h}$ at $37^{\circ} \mathrm{C}$. The samples were then analysed by Western blotting with a monoclonal antibody against phosphotyrosine. 

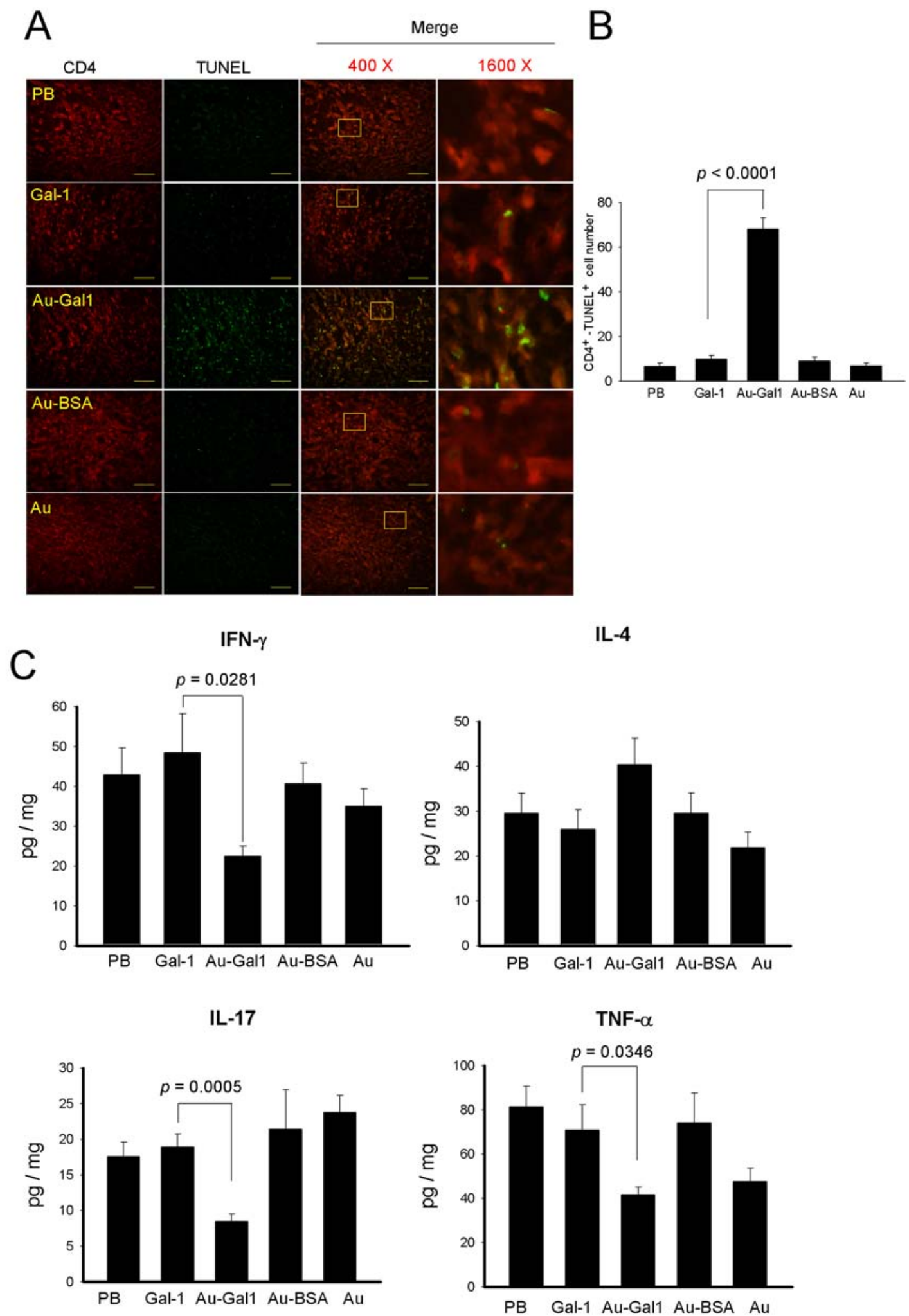

Fig. 4. Au-Gall treatment increased $\mathrm{CD}^{+} \mathrm{T}$ cells undergoing apoptosis and reduced inflammatory cytokines in the ankle joints of rats with CIA. (A) Detection of CD4 and TUNEL double-positive cells. Rats were immunised with collagen on days 0 and 8 for induction of CIA. They received different treatments on day 14. Frozen sections of ankle joints collected on day 16 were subjected to immunofluorescence staining with mouse anti-rat CD4 monoclonal antibody and Alexa fluor594 goat anti-mouse IgG. Apoptotic cells were stained with TUNEL. More apoptotic CD4 ${ }^{+}$ T cells were detected by TUNEL staining in Au-Gall-treated synovial tissues. In the merged images, the right panels are higher-magnification views (original magnification $\times 2,000$ ) of the respective boxed areas in the left (original magnification $400 \times$, scale bar $=20 \mu \mathrm{m}$ ). (B) Number of CD4 and TUNEL double-positive cells in three randomly selected high-power fields (original magnification $\times 400$ ) in each section. (C) Levels of IFN- $\gamma$, IL-4, IL-17 and TNF- $\alpha$ in the ankle homogenates of rats with CIA on day 16 were quantified by ELISA. Bars show the mean \pm SEM from 6 samples per treatment group for $\mathrm{b}$ and $\mathrm{c}$. 


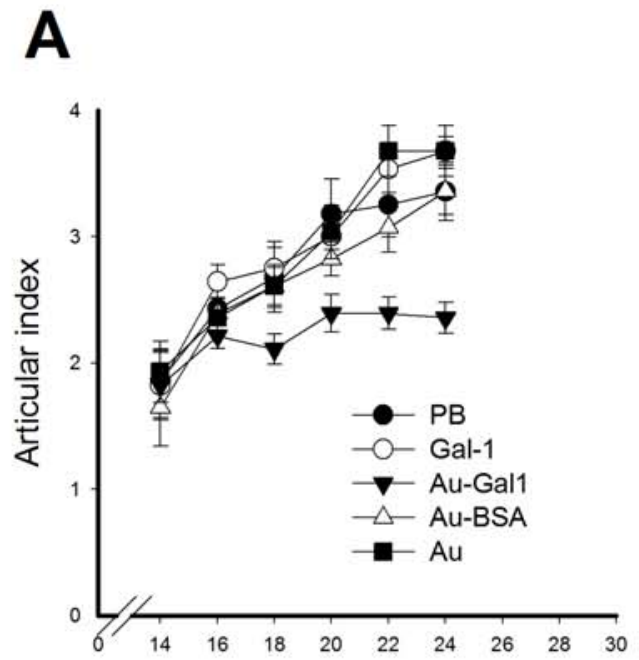

Days after first immunisation
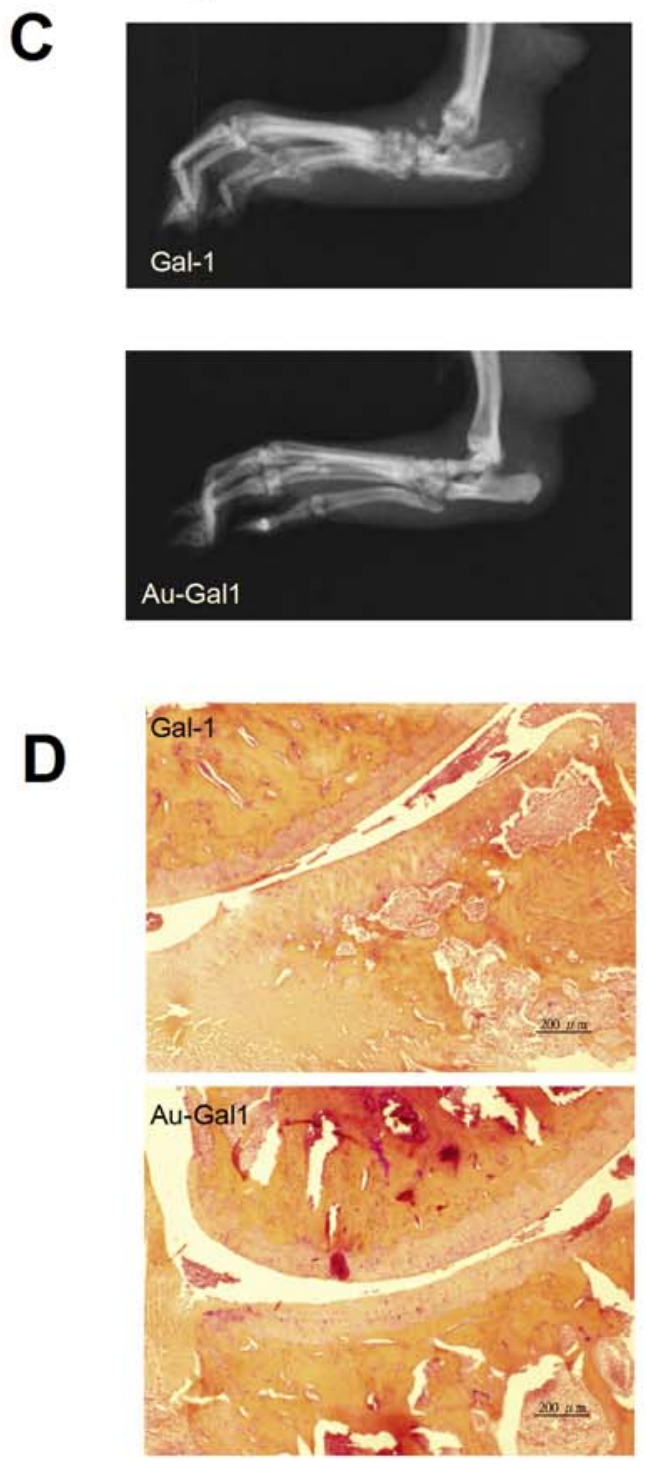

B

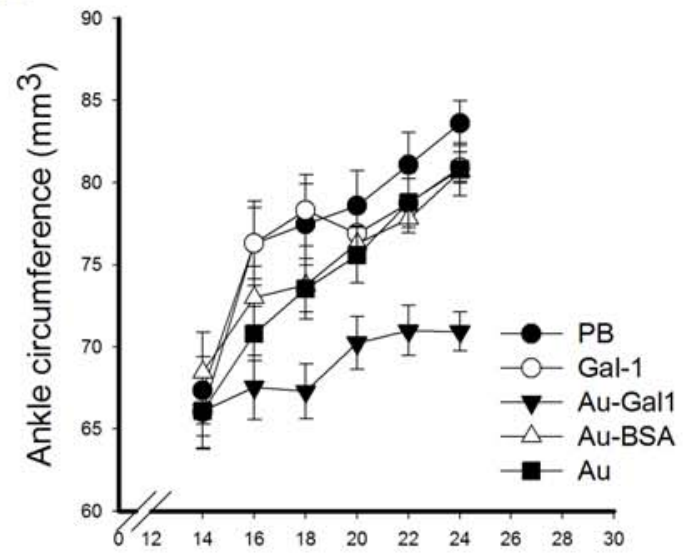

Days after first immunisation
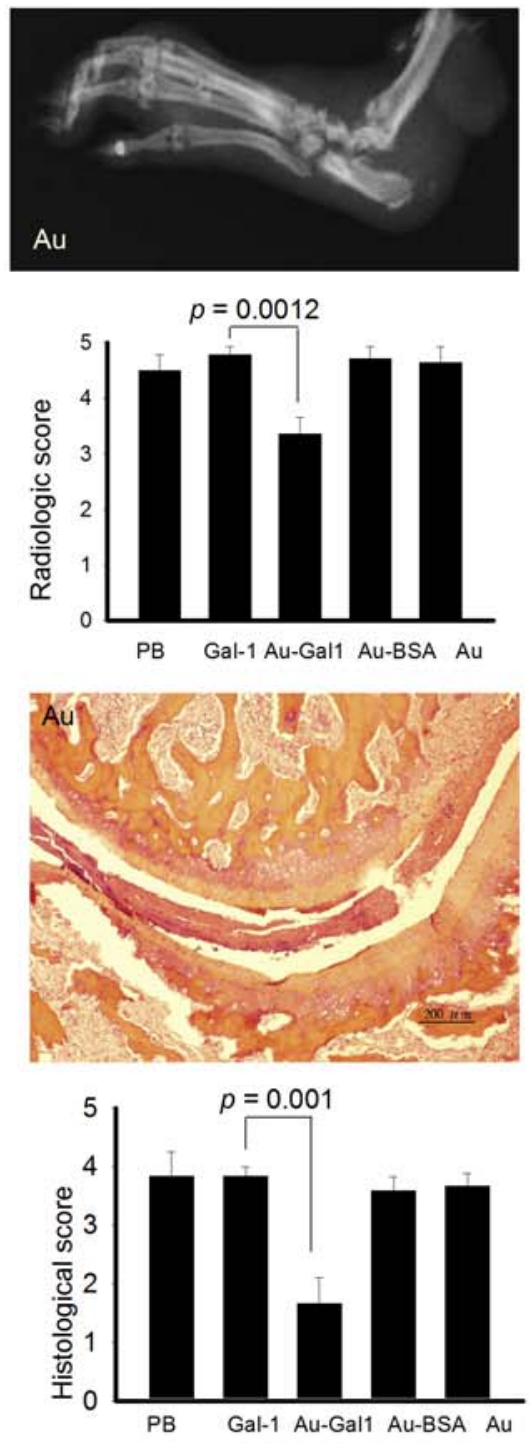

Fig. 5. Au-Gall treatment ameliorated clinical symptoms in rats with CIA. Rats were immunised with collagen on days 0 and 8 for induction of CIA. They received different treatments on day 14. (A) Reduction in the articular index score in the rats treated with Au-Gal1. (B) Reduction in the ankle circumference in the rats treated with Au-Gal1. Bars in a and $\mathrm{b}$ show the mean \pm SEM in 12 feet per group. (C) Representative photographs of the rat ankles on day 24. The results of plain radiography revealed that Au-Gall-treated rats had more intact joint structure as compared with their control counterparts. Au-Gall reduced the radiologic scores on day 24 in rats. Bars show the mean \pm SEM for 6 rats per group. (D) Representative histologic score and haematoxylin and eosin-stained joint sections on day 24. Results are the mean $\pm \mathrm{SEM}$ for 6 rats per group. 
activity, leading to enhanced galectin-1-induced cell death (Walzel et al., 1999). Fig. 3D demonstrates that cellular tyrosine phosphorylation was increased after treatment with Au-Gall in a time-dependent manner, and it was significantly higher in cells treated with Au-Gall compared with the other treatments. However, enhancement of tyrosine phosphorylation was abolished in the presence of lactose (Fig. 3E). Taken together, these results indicate that the multivalent structure of Au-Gall enhanced CD45 clustering, which led to modulation of membrane receptor signalling and alterations in cell behaviour.

\section{Au-Gal1 enhanced CD4 ${ }^{+} \mathrm{T}$ cell apoptosis and ameliorated clinical symptoms of CIA}

To further investigate the role of Au-Gall in promoting the apoptosis of $\mathrm{CD}^{+} \mathrm{T}$ cells in vivo as well as evaluate its therapeutic feasibility, galectin-1, Au-Gal1, Au-BSA or nanogold were administered intra-articularly to rats with CIA. Tissues from arthritic joints after $48 \mathrm{~h}$ of treatment were examined for apoptosis by TUNEL assay and for $\mathrm{CD}^{+} \mathrm{T}$ cells by immunohistochemical staining (Fig. 4A). A three-fold increase in apoptotic $\mathrm{CD}^{+} \mathrm{T}$ cells and lower numbers of infiltrating CD4 ${ }^{+} \mathrm{T}$ cells were observed in the synovial tissue of animals treated with $\mathrm{Au}-\mathrm{Gall}$, compared to those treated with galectin-1 only (Fig. 4B). As shown in Fig. 4C, the levels of the Th1 cytokine interferon- $\gamma$ (IFN- $\gamma$ ), the Th17 cytokine interleukin (IL)-17 and the pro-inflammatory cytokine tumour necrosis factor- $\alpha$ (TNF- $\alpha$ ) in the joint extracts were reduced by $50 \%$ in the Au-Gal1-treated group compared with the Gal-1-treated group. However, the levels of IL-4 were not significantly altered in the Au-Gal1-treated group compared to the remaining groups (Fig. 4C). To further evaluate the therapeutic effects of Au-Gall on CIA, rats immunised twice with collagen were injected intra-articularly with Au-Gal1, PB, galectin-1, Au-BSA or nanogold after the onset of CIA. Both ankle circumference (Fig. 5A) and articular index score (Fig. 5B) were significantly smaller in the AuGal1-treated group than in the two control groups. We next assessed the radiographic and histologic changes in the ankle joints after the animals were sacrificed on day 24. Joint space narrowing and bone erosion were observed in the ankles treated with galectin-1, Au, Au-BSA or PB but were markedly attenuated in the AuGall-treated ankles. The radiologic score, which was on the basis of width of the joint space, degree of bone destruction and soft-tissue swelling, was also significantly lower in the $\mathrm{Au}-\mathrm{Gall}$-treated group than in the control groups (Fig. 5C). To confirm the improvement of clinical symptoms, histological evaluation of the joint tissues was conducted. Histopathologic analysis of galectin-1-, Au-, Au-BSA- or PB-treated joint tissues revealed synovial hyperplasia and obvious bone erosion. However, the joint tissues from Au-Gal1-treated animals showed relatively intact cartilage on the joint surface and slight hyperplasia of the synovial membrane. Furthermore, the histologic score was significantly lower in the AuGal1-treated group than in the other groups (Fig. 5D). Collectively, these findings indicate that treatment with $\mathrm{Au}-\mathrm{Gal1}$ reduced the severity of arthritic symptoms in rats with CIA, as determined by examination of the clinical, radiographic and histologic features of their ankle joints. Immunohistochemical staining also demonstrated that fewer infiltrating $\mathrm{CD}^{+} \mathrm{T}$ cells, macrophages and microvessels were present in the synovium of the Au-Gal1-treated group compared to the control groups (Fig. 6A, B, C). These results suggest that the beneficial effect of Au-Gall on arthritic symptoms may be attributed to its cytotoxic effect on infiltrating $\mathrm{CD} 4^{+} \mathrm{T}$ cells in arthritic tissues. Taken together, our data showing that Au-Gall reduced the severity of CIA as indicated by the clinical, radiographic and histologic features suggest that Au-Gall nanoparticles act as a multivalent form of galectin-1 and may be more effective than other molecules in protecting joint integrity.

\section{Discussion}

Nanoparticles have been engineered into biosensors, molecular scale fluorescent tags, imaging agents, targeted molecular delivery vehicles and other useful biological tools with chemically modifiable surfaces onto which various ligands can attach (Liu et al., 2007). The multivalent enhancement of the $\mathrm{K}_{\mathrm{D}}$ is a key factor in improving biological targeting by drug delivery platforms (Hong et al., 2007). Multivalent nanoparticles coated with targeting peptides have been studied in image and therapeutic systems (Huang et al., 2009; Shokeen et al., 2011). In this work, we investigated a new application of nanoparticles to reveal the multivalent effects of biological molecules. When galectin-1 was conjugated to nanoparticles, the resulting complex, Au-Gall, led to increased binding affinity to target cells and enhancement of $\mathrm{T}$ cell apoptosis by the clustering of CD45 molecules. Clustered CD45 molecules promoted apoptosis via caspase-dependent pathways. Nanoparticles therefore not only play a role in vector delivery to increase payload influx or imaging detection, but they can also be conjugated to ligands to regulate receptor distribution and downstream cell signalling.

In CIA, Au-Gal1 enhanced CD4 ${ }^{+} \mathrm{T}$ cell apoptosis and reduced the production of Th1 and Th17 cytokines, as well as TNF- $\alpha$ in the synovium. Here, low doses of Au-Gall showed better therapeutic effects than free galectin-1. In our previous study, administration of gold nanoparticles in the early stages of CIA reduced disease progression by inhibiting vascular endothelial growth factor (VEGF) activity, but this strategy proved less effective at reducing the severity of arthritis when administered after the onset of the disease. In the current study, the clinical, radiographic and histologic features in rats were reduced by Au-Gall administration after the onset of disease. Thus, in the later stages of disease, therapeutic targeting of T cells was more effective than targeting VEGF in reducing the severity of the disease in the joint.

In conclusion, our study provides a novel approach for the application of nanoparticles, because the multivalent property of the nanostructure actively regulates membrane receptor organisation to affect cell signalling. This concept will have a significant impact on the design of nanodevices with great potential for therapeutic applications. 
A
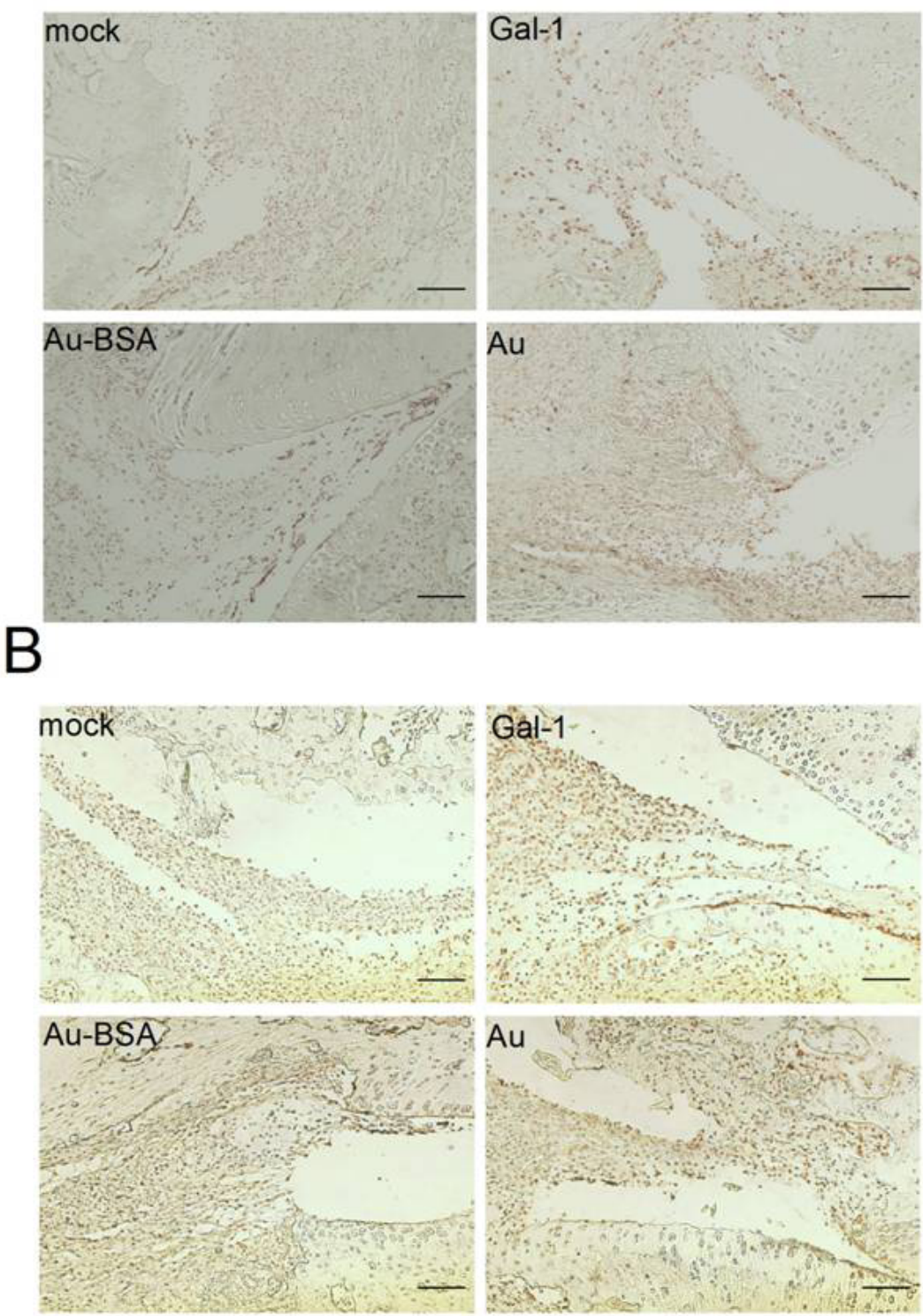

C
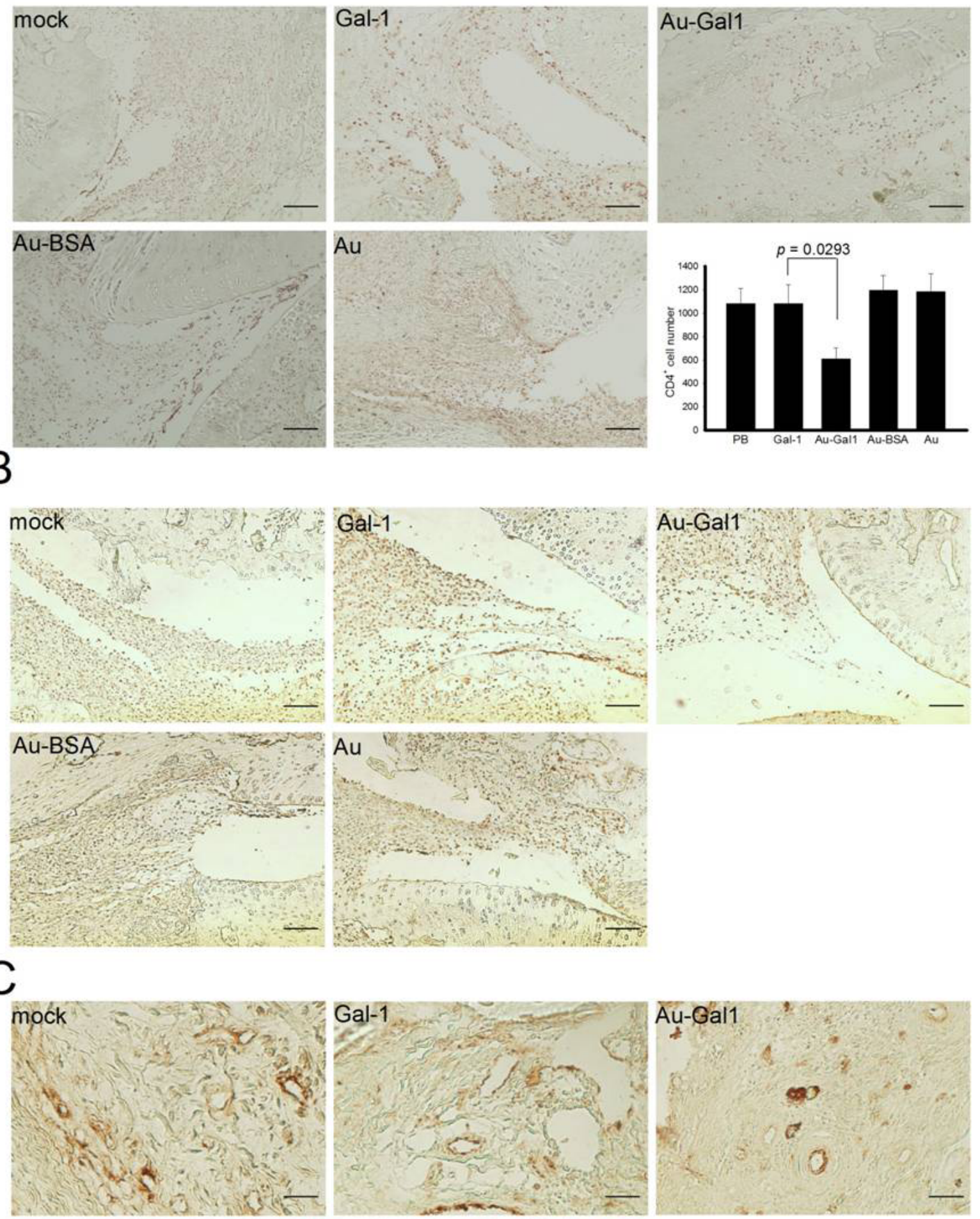

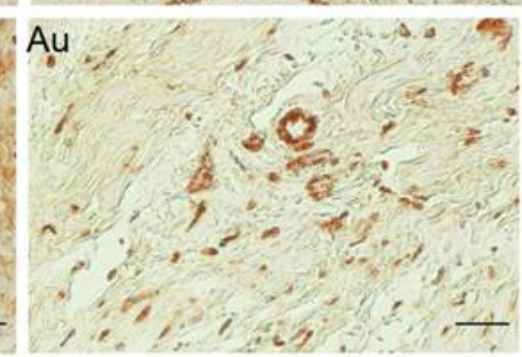




\section{Acknowledgements}

This work was supported by grants (NSC 95-2320-B-006076-MY3 and NSC 98-2628-B-006-014-MY3) from the National Science Council, Taiwan.

\section{References}

Amano M, Galvan M, He J, Baum LG (2003) The ST6Gal I sialyltransferase selectively modifies N-glycans on CD45 to negatively regulate galectin-1-induced CD45 clustering, phosphatase modulation, and $\mathrm{T}$ cell death. J Biol Chem 278: 7469-7475.

Brandt B, Büchse T, Abou-Eladab EF, Tiedge M, Krause E, Jeschke U, Walzel H (2008) Galectin-1 induced activation of the apoptotic death-receptor pathway in human Jurkat T lymphocytes. Histochem Cell Biol 129: 599-609.

Camby I, Le Mercier M, Lefranc F, Kiss R (2006) Galectin-1: a small protein with major functions. Glycobiology 16: 137R-157R.

Chen SY, Wu CL, Lai MD, Lin CC, Yo YT, Jou IM, Lee CH, Weng CT, Shiau AL, Wang CR (2011) Amelioration of rat collagen-induced arthritis through $\mathrm{CD}^{+} \mathrm{T}$ cell apoptosis and synovial interleukin-17 reduction by indoleamine 2,3-dioxygenase gene therapy. Hum Gene Ther 22: 145 154.

Earl LA, Bi S, Baum LG (2010) N- and O-glycans modulate galectin-1 binding, CD45 signaling, and T cell death. J Biol Chem 285: 2232-2244.

Fouillit M, Joubert-Caron R, Poirier F, Bourin P, Monostori E, Levi-Strauss M, Raphael M, Bladier D, Caron M (2000) Regulation of CD45-induced signaling by galectin-1 in burkitt lymphoma B cells. Glycobiology 10: 413-419.

Garner OB, Baum LG (2008) Galectin-glycan lattices regulate cell-surface glycoprotein organization and signalling. Biochem Soc Trans 36: 1472-1477.

Gestwicki JE, Cairo CW, Strong LE, Oetjen KA, Kiessling LL (2002) Influencing receptor-ligand binding mechanisms with multivalent ligand architecture. J Am Chem Soc 124: 14922-14933.

Hermiston ML, Xu Z, Weiss A (2003) CD45: a critical regulator of signaling thresholds in immune cells. Annu Rev Immunol 21: 107-137

Hong S, Leroueil PR, Majoros IJ, Orr BG, Baker JR Jr, Banaszak Holl MM (2007) The binding avidity of a nanoparticle-based multivalent targeted drug delivery platform. Chem Biol 14: 107-115.

Huang YF, Liu H, Xiong X, Chen Y, Tan W (2009) Nanoparticle-mediated IgE-receptor aggregation and signaling in RBL mast cells. J Am Chem Soc 131: 1732817334.

Inagaki Y, Sohma Y, Horie H, Nozawa R, Kadoya T (2000) Oxidized galectin-1 promotes axonal regeneration in peripheral nerves but does not possess lectin properties. Eur J Biochem 267: 2955-2964.

Jiang W, Kim BY, Rutka JT, Chan WC (2008) Nanoparticle-mediated cellular response is size-dependent. Nat Nanotechnol 3: 145-150.
Lange F, Brandt B, Tiedge M, Jonas L, Jeschke U, Pöhland R, Walzel H (2009) Galectin-1 induced activation of the mitochondrial apoptotic pathway: evidence for a connection between death-receptor and mitochondrial pathways in human Jurkat T lymphocytes. Histochem Cell Biol 132: 211-223.

Liu Y, Miyoshi H, Nakamura M (2007) Nanomedicine for drug delivery and imaging: a promising avenue for cancer therapy and diagnosis using targeted functional nanoparticles. Int J Cancer 120: 2527-2537.

Motran CC, Molinder KM, Liu SD, Poirier F, Miceli MC (2008) Galectin-1 functions as a Th2 cytokine that selectively induces Th1 apoptosis and promotes Th2 function. Eur J Immunol 38: 3015-3027.

Nguyen JT, Evans DP, Galvan M, Pace KE, Leitenberg D, Bui TN, Baum LG (2001) CD45 modulates galectin1-induced T cell death: regulation by expression of core 2 O-glycans. J Immunol 167: 5697-5707.

Pang M, He J, Johnson P, Baum LG (2009) CD45mediated fodrin cleavage during galectin-1 $\mathrm{T}$ cell death promotes phagocytic clearance of dying cells. J Immunol 182: 7001-7008.

Rabinovich GA, Daly G, Dreja H, Tailor H, Riera CM, Hirabayashi J, Chernajovsky Y (1999) Recombinant galectin-1 and its genetic delivery suppress collageninduced arthritis via T cell apoptosis. J Exp Med 190: 385-398.

Rabinovich GA, Toscano MA, Jackson SS, Vasta GR (2007) Functions of cell surface galectin-glycoprotein lattices. Curr Opin Struct Biol 17: 513-520.

Shankaran H, Resat H, Wiley HS (2007) Cell surface receptors for signal transduction and ligand transport: a design principles study. PLoS Comput Biol 3: e101.

Shiau AL, Chen SY, Chang MY, Su CH, Chung SY, Yo YT, Wang CR, Wu CL (2007) Prothymosin $\alpha$ lacking the nuclear localization signal as an effective gene therapeutic strategy in collagen-induced arthritis. J Immunol 178: 4688-4694.

Shokeen M, Pressly ED, Hagooly A, Zheleznyak A, Ramos N, Fiamengo AL, Welch MJ, Hawker CJ, Anderson CJ (2011) Evaluation of multivalent, functional polymeric nanoparticles for imaging applications. ACS Nano 5: 738747.

Toscano MA, Bianco GA, Ilarregui JM, Croci DO, Correale J, Hernandez JD, Zwirner NW, Poirier F, Riley EM, Baum LG, Rabinovich GA (2007) Differential glycosylation of $\mathrm{T}_{\mathrm{H}} 1, \mathrm{~T}_{\mathrm{H}} 2$ and $\mathrm{T}_{\mathrm{H}}-17$ effector cells selectively regulates susceptibility to cell death. Nat Immunol 8: 825-834.

Trowbridge IS and Thomas ML (1994) CD45: an emerging role as a protein tyrosine phosphatase required for lymphocyte activation and development. Annu Rev Immunol 12: 85-116.

Tsai CY, Shiau AL, Chen SY, Chen YH, Cheng PC, Chang MY, Chen DH, Chou CH, Wang CR, Wu CL (2007) Amelioration of collagen-induced arthritis in rats by nanogold. Arthritis Rheum 56: 544-554.

Van der Heijde DM (1995) Joint erosions and patients with early rheumatoid arthritis. Br J Rheumatol 34 (suppl 2): 74-78. 
Walzel H, Schulz U, Neels P, Brock J (1999) Galectin-1, a natural ligand for the receptor-type protein tyrosine phosphatase CD45. Immunol Lett 67: 193-202.

Wang CR, Chen SY, Wu CL, Liu MF, Jin YT, Chao L, Chao J (2005) Prophylactic adenovirus-mediated human kallistatin gene therapy suppresses rat arthritis by inhibiting angiogenesis and inflammation. Arthritis Rheum 52: 13191324.

Wang CR, Shiau AL, Chen SY, Cheng ZS, Li YT, Lee $\mathrm{CH}$, Yo YT, Lo CW, Lin YS, Juan HY, Chen YL, Wu CL (2010) Intra-articular lentivirus-mediated delivery of galectin-3 shRNA and galectin-1 gene ameliorates collagen-induced arthritis. Gene Ther 17: 1225-1233.

\section{Discussion with Reviewer}

C. de Bari: Did the authors detect any side effects after intra-articular administration of Au-Gal1?

Authors: During the 24 day observation period, rats treated intra-articularly with Au-Gall did not show noticeable adverse effects as they looked healthy and vigorous. However, long-term studies are required to examine the potential toxicity of Au-Gal1.

C. de Bari: Rheumatoid arthritis tends to be polyarticular, hence requiring systemic treatment. Do the authors envisage a systemic route of administration of the AuGal1? If so, which one? What would the expected side effects be?

Authors: Because RA is a systemic disease that commonly involves multiple joints and several organs, systemic administration may be more suitable for the clinical setting. However, since $\mathrm{T}$ cells are the main target of $\mathrm{Au}-\mathrm{Gal1}$, the authors cannot exclude the possibility that systemic delivery of Au-Gal might also induce apoptosis and hence reduce the number of circulating T cells. Using the intra-articular route of administration, Nagata and colleagues (Nagata et al., 2009, additional reference) showed that injection of double-stranded microRNA may move from the joint cavity into the systemic circulation as higher levels of microRNA-15a were detected in the liver, suggesting that the effect of intra-articular administration is not restricted to the injected joints. In this regard, whether intra-articular injection of Au-Gall can gain access into the systemic circulation deserves further experimental investigation. It would also be of interest to compare intraarticular and systemic routes of Au-Gall administration in animal models of arthritis in terms of therapeutic effects and potential side effects.
C. de Bari: Where would the authors position the AuGall in the current treatment algorithm of inflammatory arthritis? Do they see potential for a specific clinical niche? Authors: The present study provides a proof-of-concept for the use of Au-Gall as a novel therapeutic agent for the treatment of RA. Compared to our previous study (Tsai et al., 2007, text reference) showing that nanogold alone can reduce arthritis symptoms in the rat CIA model when administered before, but not after the onset of the disease due to its anti-angiogenic activity, Au-Gall is more effective as a therapeutic agent. The results presented in this study suggest that $\mathrm{T}$ cells may serve as a therapeutic target for RA even after neovascularisation has been established in the early stages of arthritis. AuGall may have therapeutic effects in the late stages of arthritis to prevent disease progression. Biologically-based immunotherapies, such as TNF- $\alpha$ antagonists, have been marketed for treating RA and have improved the life quality of many patients. However, a substantial number of patients have an inadequate or unsustained response. Au-Gall may have its niche to serve as a T cell-targeted therapeutic agent for RA.

C. de Bari: What would be the advantages of intra-articular Au-Gall over intra-articular corticosteroids?

Authors: Intra-articular injection of corticosteroids is used for the relief of joint pain and swelling through their anti-inflammatory activity. If the results from the animal study can be extrapolated to humans, we presume that the advantages of intra-articular Au-Gall over intra-articular corticosteroids would be that common and irreversible side effects of corticosteroids, such as osteoporosis, may not be expected to occur following Au-Gall treatment. Our previous report showed that nanogold can bind directly to VEGF in human RA synovial fluid and inhibit its bioactivity (Tsai et al., 2007), suggesting that Au-Gall may also exert anti-angiogenic effect when nanogold is dissociated from the Au-Gall complex.

\section{Additional Reference}

Nagata Y, Nakasa T, Mochizuki Y, Ishikawa M, Miyaki S, Shibuya H, Yamasaki K, Adachi N, Asahara H, Ochi M (2009) Induction of apoptosis in the synovium of mice with autoantibody-mediated arthritis by the intraarticular injection of double-stranded microRNA-15a. Arthritis Rheum 60: 2677-2683. 